\title{
The Effect of Learning Strategies and Motivation on Reading Texts Comprehension
}

\author{
Suriwaty $^{1 *}$, Mukhtar ${ }^{1}$ and Naeklan Simbolon ${ }^{1}$ \\ \{*suriwaty.usman@gmail.com \} \\ Department of Educational Technology, Universitas Negeri Medan, Medan, Indonesia ${ }^{1}$
}

\begin{abstract}
This study aimed to: (1) find out the comprehension ability of reading reading texts of students taught with inquiry learning strategies with students taught using expository, (2) determine reading comprehension ability of reading texts of students who have higher learning motivation with students who have low motivation, and (3) find out the interaction between learning strategies and motivations for students' reading comprehension ability. The research design was presented in factorial $2 \times 2$ design with variance analysis technique (Anava). Data collection techniques carried out were multiple choice reading comprehension tests, as well as learning motivation questionnaires. The results of the study showed: (1) students were taught with inquiry learning strategies obtained higher reading comprehension than students taught with expository strategies where (F observed $=3.830>\mathrm{F}$ table $=3.26)$, (2) students who have high learning motivation gained high reading comprehension than students who have low learning motivation where $(\mathrm{F}$ observed $=11,397>\mathrm{F}$ table $=3.26)$, (3) there was no interaction between learning strategies and motivation towards reading texts comprehension where $(\mathrm{F}$ observed $=0.456<\mathrm{F}$ table $=3.26)$.
\end{abstract}

Keywords: Learning strategy, motivation, inquiry, expository, reading comprehension

\section{Introduction}

Vocational High School (SMK) Education was one of the formal education institutions in the category of secondary education that was quite strategic in realizing the government's mandate in the field of education. Therefore, all the subjects taught must be improved in quality. In learning English was very closely related to the real world in everyday life. Teachers can open many minds of students to learn the concepts in use on the aspects contained in English subjects to solve a problem or cases and encourage students to make the connection between English materials and its application related in daily life. To explore the potential of children to always be creative and developing, it was necessary to apply meaningful learning that would bring students to a memorable learning experience.

Learning strategies also influenced students learning outcomes, the reality obtained in the field was that the average learning outcomes of students of Vocational High School (SMK PAB 12 Saentis) was still low and has not been as expected, due to the low of reading ability owned by the students. While learning English students not only was it demanded just to understand and comprehending the contents of the reading, but it must also be able to analyze, evaluate and relate it to the experiences and initial knowledge that it already has. In this regard, information on learning English must be studied by people so that learning objectives can be addressed widely to facilitate students in understanding learning. 
Based on several studies on inquiry learning. [1] showed that the results of learning conveying opinions in discussions after using the Inquiry model in grade X of Senior High School (SMA) 2 Selimbau of Kapuas Hulu District giving the significant contributions to students learning outcomes in Indonesian language learning and can improve students learning outcomes. [2] found that the influence of guided inquiry learning model can improve the learning outcomes of grade IX of Islamic Junior High School (MTs) of Madani Alauddin Paopao.

Based on those findings, it was necessary to ascertain what learning model was suitable in implementing economic learning so that students easily understood it. For this reason, one factor that needed to be considered was the learning process. It was necessary to study a more basic learning model because it required a deep understanding of English as well as existing problems so that it took a learning model and invited students to make it easier for students to understand a text reading. In connection with this the form and model of inquiry learning can be an alternative in learning English, In line with the findings of [3]inquiry learning strategy was a series that emphasized the process of learning to think critically and analytically to seek and find the answers themselves from a problem that is questionable. The process of thinking itself was usually done through question and answer between teacher and students. Other learning models that would be seen influence was expository, according to Killen [4], expository learning strategy was one of the learning strategies that emphasizes the process of delivering material verbally from a teacher to a group of students with the intention that students can master the subject matter optimal. the expository learning strategy was a form of a teacher-oriented learning approach (Teacher centered approach) said so, because in this strategy the teacher holds a very dominant role. Through this strategy the teacher delivered structured learning material in the hope that the subject matter delivered can be mastered by students well. The main focus of this strategy was the students' academic achievement.

Therefore, it was necessary to do research on the effect of learning strategy and student motivation on learning outcomes in English. The application of the learning strategy will be designed with a very efficient link covering students, teachers, learning processes and learning environments, namely inquiry and expository learning models as a factor that can affect the increase in learning outcomes.

The purpose of this study was (1) to find out the comprehension ability of reading the reading texts of students taught with inquiry learning strategies with students taught using expository, (2) to determine the reading comprehension ability of students who have higher learning motivation with students who have low motivation, and (3) to find out the interaction between learning strategies and motivations for students' reading comprehension ability.

\section{Methodology}

This research was at Vocational High School (SMK) PAB 12 Saentis. The method used in this study was a quasi experimental method with a $2 \times 2$ factorial design with a significant level of 0.05 before two-way ANAVA test was carried out, firstly it was determined the requirements of analysis, namely the normality requirements using the Liliefos Test, while the homogeneity test used the Bartlett test and the F test with the intention that the sample distribution in the study population was homogeneous. After testing the requirements of the analysis, a two-way Anava test was then carried out. If the two-way Anava was significant, 
then a further test ( post hoc test ) was held . Because the number of samples for each cell was not the same, Scheffe Test will be used.

\section{Result and Discussion}

\subsection{Results}

The hypotheses testing used variance analysis and factorial path of $2 \times 2$ (ANAVA) techniques. Research data were grouped based on the interaction between the learning model and students learning interest. The comparison of groups of student learning outcomes data based on research findings, briefly in Table 1.

Table 1. Summary of Research Result Data

\begin{tabular}{ccrrr}
\hline \multirow{2}{*}{$\begin{array}{c}\text { Motivation } \\
\text { to learn }\end{array}$} & Statistics & \multicolumn{2}{c}{ Learning model } & \\
\cline { 3 - 4 } High & $\mathrm{N}$ & Tnquiry & Ekpositori & \\
\hline \multirow{6}{*}{ Low } & $\sum \mathrm{X}$ & 544 & 20 & 39 \\
& $\sum \mathrm{X}^{2}$ & 15960 & 480 & 1024 \\
& $\mathrm{M}$ & 28.63 & 24.00 & 52.63 \\
& $\mathrm{~N}$ & 21 & 20 & 41 \\
& $\mathrm{X}$ & 424 & 274 & 698 \\
& $\sum \mathrm{X}$ & 15217 & 5612 & 20829 \\
& $\mathrm{M}$ & 20.19 & 13.70 & 33.89 \\
Total & $\mathrm{N}$ & 40 & 40 & 80 \\
& $\sum \mathrm{X}$ & 968 & 754 & 1722 \\
& $\sum \mathrm{X}$ & 31177 & 17214 & 48391 \\
& $\mathrm{M}$ & 48.82 & 37.70 & 86.52 \\
\hline
\end{tabular}

Table 2. The Summary of Factorial 2x2 Anava Calculations

\begin{tabular}{cccccc}
\hline $\begin{array}{c}\text { Source of } \\
\text { Variation }\end{array}$ & $\mathrm{JK}$ & $\mathrm{Db}$ & $\mathrm{RJK}$ & $\mathrm{F}_{\mathrm{h}}$ & $\mathrm{F}_{\text {tab }}$ \\
\hline $\mathrm{A}$ & 572.45 & 1 & 572.45 & $3,830^{*)}$ & 3.26 \\
$\mathrm{~B}$ & 1703,54 & 1 & 1703,54 & $11,397 *)$ & 3.26 \\
Inter AB & 68,102 & 1 & 68,102 & $0,456 * *)$ & 3.26 \\
in & 8980.86 & 36 & 149.47 & - & - \\
\hline Total & 11324.95 & 39 & - & - & \\
\hline
\end{tabular}

\section{a. First Hypothesis}

Based on the results of calculations, it can be seen that the value of $F_{\text {observed }}$ inter columns was greater than $\mathrm{F}_{\text {table }}\left(\mathrm{F}_{\text {observed }}=3.830>\mathrm{F}_{\text {table }}=3.26\right)$ at the significant level of $5 \%$. Thus, there was a significant difference between students learning outcomes taught by inquiry learning strategies and learning outcomes of students who were taught with expository learning strategies that were validated. In this case learning by using inquiry learning strategies was higher than learning by using expository learning strategies, because the average value of student learning outcomes taught by inquiry learning strategies (18.7) was higher than the average value of student learning outcomes taught by expository learning strategies (13.5). 


\section{b. Second Hypothesis}

Based on the results of calculations, the value of $F_{\text {observed }}$ inter columns was greater than $\mathrm{F}_{\text {table }}\left(\mathrm{F}_{\text {observed }}=11.397>\mathrm{F}_{\text {table }}=3.26\right)$ at a significant level of 5\%. Thus, Ho was rejected and Ha stated that reading comprehension of students in English Subjects who have high learning motivation was higher than those who have low learning motivation at SMK PAB 12 Saentis was validated.

\section{c. Third Hypothesis}

Based on the results of calculations, it can be seen that the value of $\mathrm{F}_{\text {observed }}$ inter columns and rows (interactions) was smaller than $\mathrm{F}_{\text {table }}\left(\mathrm{F}_{\text {observed }}=0.456<\mathrm{F}_{\text {table }}=3.26\right)$ at the significant level of 5\%. Thus, there was no interaction between the use of learning strategies and learning motivation in influencing students' reading comprehension was not validated

\subsection{Discussions}

The Economics learning outcomes of students who were treated with inquiry learning models were higher compared to students who obtained treatment with the expository learning model.

The results showed that the average result of learning English as a whole group of students who obtained inquiry learning model was higher than with a group of students who obtained expository model. This was because the students in the group of inquiry learning model emphasized on merger/combination of learning discussion method and motivation in learning. Inquiry did not mean replacing the learning model of discussion in the classroom, but strengthening the learning model, because the students not only discussed but rather sharpening students' motivation such as discussing a problem. With student's inquiry learning it has positioned them self as the active students' actors who understands their needs and strived to achieve an understanding of knowledge independently. The activities carried out by students during the learning process took place would make students eager to follow the learning process.

The results of learning English of students who have the high learning motivation higher than students who have the low learning motivation. The results showed that the average value of learning outcomes of English students who have the high motivation to learn higher than students who have low learning motivation. This indicated that students who have the high learning motivation able to understand English language lessons compared to students who have the low learning motivation.

So, there was an increase in having learning motivation. This increase was due to students being able to study well, where students can solve the questions raised, the learning model that can foster students' enthusiasm in learning.

\section{Conclusion}

Based on the results of the research and discussion previously stated, then in this study it can be concluded that:

a. There were differences in learning outcomes of reading comprehension between groups of students taught with inquiry learning strategies with students taught with expository learning strategies. 
b. There were differences in learning outcomes of reading comprehension between groups of students who have high learning motivation and groups of students who have low learning motivation.

c. There was no interaction between the application of inquiry learning strategies and expository learning strategies with high and low motivation to learn towards the learning outcomes of reading comprehension in grade X of SMK PAB 12 of Saentis.

\section{References}

[1] Khasan and Buyung, "Strategi Pembelajaran Inkuiri (SPI) Terhadap Kemampuan Pemahaman Konsep," STKIP Singkawang, 2015.

[2] Nurfausiah and Nuhardiman, "Pengaruh Model Pembelajaran Inkuiri Terbimbing Terhadap Hasil Belajar," J. Pendidik. Fis., vol. 4, no. 1, 2016.

[3] W. Sanjaya, Strategi Pembelajaran Berorientasi Standar Proses Pendidikan. Bandung: Kencana Prenada Media Grup, 2012.

[4] W. Sanjaya, Strategi Pembelajaran Berorientasi Standar Proses Pendidikan. Jakarta: Kencana Prenada Media Group, 2003. 